\title{
Fungsi Pasar Sapi/ Blante Bagi Masyarakat Minahasa
}

\section{Romi Mesra ${ }^{1}$, Maryam Lamadirisi ${ }^{2}$, Siti Fathimah ${ }^{3}$}

1,2,3 Universitas Negeri Manado

Email: romimesra@unima.ac.id, mariamlamadirisi@unima.ac.id, sitifathimah@unima.ac.id

\begin{abstract}
Abstrak
Penelitian ini menjelaskan fenomena jual beli sapi yang sudah dilakukan secara turun-temurun di Pasar Sapi/ Blante. Aktivitas jual beli sapi cenderung ramai pada waktu siang hari meskipun di pagi hari para pemilik sapi, penjual dan pembeli sudah mulai berdatangan ke lokasi tersebut. Pengunjung berasal dari berbagai suku bangsa dan agama yang beragam. Akan tetapi masyarakat pasar mampu mempertahan harmonisasi melalui nilai-nilai dan norma yang sudah melekat dalam kehidupan masyarakat Minahasa itu sendiri. Penelitian ini bertujuan untuk menjelaskan fungsi Pasar Sapi/ Blante sebagai salah satu pasar tradisional bagi masyarakat Minahasa. Penelitian ini menggunakan metode penelitian kualitatif. Teknik pengumpulan data yaitu observasi dan wawancara. Informan adalalah masyarakat yang beraktivitas di Pasar Sapi/ Blante. Teori yang dipakai yakni teori Struktural Fungsional Parsons. Teknik analisa data menggunakan Miles dan Huberman. Hasil penelitian mengungkapkan bahwa fungsi Pasar Sapi/ Blante bagi masyarakat Minahasa adalah melestarikan sejarah pekerjaan jual beli sapi, sarana memupuk sikap toleransi, tempat berinteraksi antar masyarakat Minahasa dan masyarakat luar, implementasi falsafah hidup masyarakat Minahasa "sitou timou tumou tou", ladang mata pencaharian masyarakat, dan sebagai wadah pelestarian bahasa daerah Minahasa.
\end{abstract}

\section{Kata kunci: Fungsi, Masyarakat Minahasa, Pasar Sapi/ Blante}

\begin{abstract}
The research departs from the phenomenon of the increasingly displaced local cultural values in the Minahasa community due to the currents of modernization and globalization in the 4.0 era which covers various aspects of life including tradition and culture. This study aims to reveal how the function of the Cow/Blante Market as a traditional market in maintaining the values of local wisdom of the Minahasa community. This study used qualitative research methods. The results of this study are: preserving the history of the work of buying and selling cows as a livelihood that has been carried out for generations, a means of fostering religious tolerance in the Minahasa community, a place for interaction between the Minahasa community and outsiders, implementing the Minahasa community's philosophy of life "sitou timou tumou tou", as a community livelihood field in the form of buying and selling cows, as a place for preserving the Minahasa regional language.
\end{abstract}

Keyword: Function, Minahasa community, Pasar Sapi/ Blante

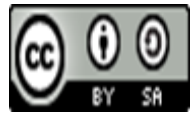

Received: October 23, 2020

Revised: December 28, 2021 Available Online: December 31, 2021 


\section{Pendahuluan}

Minahasa merupakan salah satu daerah perdagangan di wilayah Sulawesi Utara. Pusatnya terletak di tiga pasar besar yaitu Pasar Tondano, Langowan, dan Kawangkowan. Pasar Tondano berada di ibu kota kabupaten, lebih padat dibandingkan dengan dua pasar besar lainnya. Jumlah pedagang di pasar tersebut bisa mencapai 483 orang. Sementara itu, pasar Langowan dan Kawangkowan digunakan oleh pedagang sekitar 568 dan 358 setiap harinya. Dalam hal ini, pasar tradisional di Kabupaten Minahasa juga menjadi salah satu muara pertemuan berbagai kalangan, tentu saja dengan berbagai kepentingan serta latar belakang yang berbeda.

Pasar tradisional ini tidak hanya diisi oleh warga Minahasa saja, akan tetapi juga ada masyarakat pendatang yang sudah menetap, pengunjung dari luar daerah maupun pengunjung dari manca negara. Hal itu disebabkan oleh posisi pasar yang sangat strategis dalam proses sosialisasi kebudayaan maupun pencampuran berbagai kebudayaan dari orang yang berinteraksi di pasar tradisional ini. Tentu dalam proses pencampuran budaya seperti ini ada kemungkinan terjadinya pengaruh budaya yang lebih kuat yang dapat mempengaruhi budaya Minahasa itu sendiri. Bahkan bisa saja budaya Minahasa akan berangsur-angsur hilang dan tergantikan oleh budaya baru yang lebih kuat, yang berujung pada terjadinya pencampuran budaya.

Berdasarkan permasalahan di atas maka penelitian ini penting dilakukan sebagai upaya untuk mengidentifikasi pengaruh perubahan zaman terhadap eksistensi budaya lokal, terutama fungsi pasar tradisional sebagai salah satu tempat bertemunya berbagai arus budaya. Tujuan penelitian ini adalah untuk menjelaskan fungsi Pasar Sapi/ Blante bagi masyarakat Minahasa. Temuan penelitian ini memberikan sumbangan positif terhadap perkembangan spesialisasi sub kajian sosiologi pasar yang masih terbatas dikaji oleh para peneliti dan para akademisi disiplin keilmuan sosiologi, serta berkontribusi untuk meningkatkan pengetahuan masyarakat untuk menjaga eksistensi pasar tradisional sebagai wujud penjagaan nilai-nilai kearifan lokal masyarakat Minahasa.

Penelitian terkait kajian ini telah dilakukan oleh beberapa peneliti diantaranya berjudul Nilai-nilai Kearifan Lokal (Local Wisdom) Tradisi Memitu Pada Masyarakat Cirebon (Studi Masyarakat Desa Setupatok Kecamatan Mundu). Hasil penelitian menunjukkan bahwa tradisi memitu (selamatan Nujuh Bulan) memiliki nilai-nilai kesadaran religi, psikologis kesehatan ibu hamil, dapat memelihara integritas sosial dan pelestarian budaya sebagai perwujudan identitas sosial dan budaya masyarakat (Basyari \& Warii, 2014). Begitu juga penelitian Siti Fathimah tentang kebudayaan Minangkabau di Luhak Agam. Wilayah ini memiliki tradisi yang masih kuat untuk menyatukan masyarakat Minangkabau. Hukum adat di wilayah ini membuat masyarakat merasa terlindungi sehingga memunculkan perasaan takut untuk melanggar aturan adat tersebut. Hukum adat menjadi prinsip hidup sekaligus pedoman hidup bermasyarakat dengan tujuan menciptakan keamanan, disiplin dan menciptakan masyarakat yang berbudi luhur dan akhlak mulia (Fathimah \& Eriyanti, 2018).

Tulisan tersebut dikembangkan oleh Maryam Lamadirisi dan kawan-kawan yang mengulas faktor pendukung terintegrasinya masyarakat Minangkabau di Luhak Tanah Datar. Faktor itu terletak pada sistem filosofis konvensional yang berlandaskan pada ajaran Islam, bahasa, kesenian, sistem kekerabatan, dan adat istiadat. Selain itu, terpeliharanya unsur budaya yang masih kental dan menjadikan masyarakat tetap eksis dengan filosofi adatnya yaitu adat basandi syara', syara' basandi kitabbullah. Hal ini menjadi pedoman bagi setiap masyarakat agar kondisi masyarakat terjalin rapi (Lamadirisi, Fathimah, \& Sidik, 2020).

Daerah Manando menurut Bagit telah mengalami perubahan budaya lokal. Salah satunya bisa dilihat melalui model pakaian remaja pada saat ini dalam penelitiannya yang berjudul Orientasi Nilai Budaya di Kalangan Perempuan terhadap Model Pakaian di Manado. Hasil

Jurnal Socius: Journal of Sociology Research and Education Vol. 8, No. 2, Th. 2021 
penelitian menunjukkan bahwa terjadinya pergeseran nilai dan budaya cara berpakaian serta turunnya nilai moral adat 'ketimuran' yang dianut oleh masyarakat Manado (Bagit, 2017). Padahal nilai-nilai kearifan lokal adalah sesuatu yang mesti diwariskan dan melekat kuat dalam masyakarat lokal serta diwujudkan dalam kehidupan sehari-hari (Fatmawati \& Prasetya, 2021). Solusinya menurut Suwarlan (2021) dan Syafrini (2020) dalam melestarikan budaya dan warisan Indonesia dilakukan melalui wisata budaya (Syafrini, Nurdin, Sugandi, \& Miko, 2020) (Suwarlan, 2021). Tetapi menurut Setyabudi dkk (2021) nilai-nilai kearifan lokal tidak berwujud dalam bentuk kegiatan akan tetapi berbentuk bangunan arsitektur rumah adat masyarakat tersebut (Setyabudi, Santoso, \& Albina, 2021).

Begitu juga dalam penelitian Veronika E.T. Salem yang berjudul Preservation of Local Language Culture in Toundanouw Village District Southeast Minahasa Regency, menjelaskan tanggung jawab masyarakat untuk melestarikan dan menjaga budaya mereka dan nilai-nilai yang terkandung dalam budaya tersebut. Seperti halnya Pasar Sapi/ Blante yang berfungsi untuk melestarikan nilai-nilai kearifan lokal masyarakat Minahasa (Salem, Veronika, \& Mesra, 2020).

Berbagai penelitian di atas menunjukkan bahwa pasar tradisional berfungsi positif dalam mendukung integrasi sosial dalam masyarakat. Namun, tulisan-tulisan tersebut belum menjelaskan secara spesifik kaitan antara peran pasar tradisional dalam memelihara nilai-nilai kearifan lokal, khususnya nilai-nilai kearifan lokal masyarakat Minahasa. Oleh sebab itu maka penelitian ini memiliki spesifikasi objek kajian tersendiri sehingga diharapkan hasil penelitian ini nantinya akan memperkaya khazanah keilmuan sosial, khususnya bidang kajian sosiologi.

\section{Metode Penelitian}

Penelitian ini menggunakan metode kualitatif. Pendekatan kualitatif berguna untuk pemahaman yang lebih mendalam tentang makna dan konteks tingkah laku serta proses yang terjadi (Afrizal, 2014) (Denzin \& Lincoln, 2009) . Pendekatan ini digunakan untuk mengungkapkan fungsi pasar tradisional dalam memelihara nilai-nilai kearifan lokal masyarakat Minahasa. Teknik pengumpulan data dalam penelitian ini dilakukan dengan wawancara mendalam dan observasi. Dalam penelitian ini peneliti melakukan wawancara mendalam terhadap informan yang beraktifitas di Pasar Sapi/ Blante, Kabupaten Minahasa. Wawancara peneliti lakukan dengan mengunjungi pasar tersebut untuk menemukan informan yang memungkinkan diwawancara sesuai kriteria informan penelitian.

Observasi dilakukan dengan cara menjadi bagian dari masyarakat pasar tradisional tersebut, di mana peneliti mengunjungi Pasar Sapi/ Blante di Kabupaten Minahasa dan berbaur dengan aktifitas masyarakat pasar tradisonal tersebut. Data primer dalam penelitian ini adalah hasil observasi yang peneliti lakukan di lapangan atau lokasi penelitian dan wawancara yang peneliti lakukan terhadap masyarakat di Pasar Sapi/ Blante, Kabupaten Minahasa. Teknik analisis data dalam penelitian ini menggunakan teknik analisis data Miles dan Huberman (Miles \& Huberman, 1994), mengemukakan bahwa aktivitas dalam analisis data kualitatif dilakukan secara interaktif dan berlangsung secara terus menerus sampai tuntas, sehingga datanya jenuh. Ukuran kejenuhan data ditandai dengan tidak diperolehnya lagi data atau informasi baru. Aktivitas dalam analisis meliputi reduksi data (data reduction), penyajian data (data display) serta penarikan kesimpulan dan verifikasi (conclusion drawing / verification).

\section{Hasil dan Pembahasan}

\section{Melestarikan Sejarah Pekerjaan Jual Beli}

Jurnal Socius: Journal of Sociology Research and Education Vol. 8, No. 2, Th. 2021 
Setiap pasar tradisional memiliki sejarah masa lalu berkaitan dengan budaya masyarakat setempat. Alasan utama tentunya didorong oleh kebutuhan masyarakat akan pemenuhan kebutuhannya ataupun alasan-alasan lain yang mendasari didirikannya pasar itu pada zaman dahulu. Hal ini berlaku bagi pasar tradisional yang sudah lama didirikan oleh masyarakat setempat bahkan keberadaannya sudah ada semenjak nenek moyang masyarakat mulai menempati tempat tersebut, hingga beberapa generasi sesudahnya. Berarti sudah hitungan puluhan atau ratusan tahun seperti halnya keberadaan Pasar Sapi/ Blante di Kawangkowan ini. Berdasarkan wawancara dengan masyarakat setempat, seperti yang diungkapkan oleh YM (58 Tahun) sebagai berikut.

“...Seingat kita pasar ini so dari dulu ada, dari kita kecil so dibawa ke ini pasar sama kita pe orang tua, kita bahkan nyanda inga dari tahun berapa ini pasar ada, taunya so lama, dari nenek moyang kita dulu" (Wawancara pada tanggal 8 Oktober 2020).

Artinya:

“... Seingat saya pasar ini sudah ada dari dulunya, sejak saya kecil sudah dibawa ke pasar ini oleh orang tua, saya bahkan tidak ingat dari tahun berapa pasar ini ada, tahunya sudah semenjak lama, dari nenek moyang saya dulu" (Wawancara pada tanggal 8 Oktober 2020).

Senada dengan informasi yang disampaikan oleh PA (45 Tahun) sebagai berikut.

“...Kita jualan sapi di sini melanjutkan usaha kita pe bapak, dari kecil kita so iko bapak ke pasar sapi ini kong waktu itu nyanda terlalu mangarti soal usaha ini, setelah kita basar baru kita mulai menekuni pekerjaan jualan sapi ini" (Wawancara pada tanggal 8 Oktober 2020).

Artinya:

“...Saya jualan sapi di sini melanjutkan usaha ayah saya, dari kecil saya sudah ikut ayah ke pasar sapi ini walaupun waktu itu belum terlalu mengerti soal usaha ini, setelah saya besar baru saya mulai menekuni pekerjaan jualan sapi ini”" (Wawancara pada tanggal 8 Oktober 2020).

Informan di atas menyampaikan bahwa kegiatan jual beli sapi di Pasar Sapi/ Blante ini sudah dilakukan oleh orang tua, kakek dan nenek, serta nenek moyang mereka sehingga jarak yang sudah lama itu sudah tidak dapat lagi diketahui awal mula didirikannya pasar tersebut. Berkemungkinan pasar tersebut sudah ada semenjak tahun 60-an atau 70-an. Jadi, Pasar Sapi/ Blante selain berfungsi sebagai tempat kegiatan jual beli sapi secara turun temurun, juga mengandung nilai sejarah yang sangat melekat bagi masyarakat setempat sehingga menjadi identitas kehidupan mereka.

Selanjutnya juga diungkapkan RN (57 Tahun) sebagai berikut.

“...Tante so lama sekali tahu ini pasar, dari kicil so main ke sini, dulu pernah sekali pindah ke seberang jalan kong nyanda lama pindah lagi ke lokasi ini. Yang di seberang jalan pun masih merupakan lokasi pasar blante ini" (Wawancara pada tanggal 8 Oktober 2020).

Artinya:

“...Tante sudah lama sekali tahu pasar ini, dari kecil sudah main ke sini, dulu pernah pindah satu kali ke seberang jalan namun tidak lama pindah lagi ke sini. Yang di 
seberang jalan pun masih merupakan lokasi pasar blante ini" (Wawancara pada tanggal 8 Oktober 2020).

Selanjutnya juga diungkapkan IL (61 Tahun) sebagai berikut.

“...Sudah dari dulu dang ini pasar selalu ramai oleh penjual sapi, pengunjung, maupun pembeli. Mereka datang banyak dari luar daerah, nyanda cuma dari sini, ada untuk dijual lagi, untuk ternak, atau dikonsumsi sandiri" (Wawancara pada tanggal 8 Oktober 2020).

Artinya:

“...Sudah dari dulu pasar ini selalu ramai oleh penjual sapi, pengunjung, maupun pembeli. Mereka datang banyak dari luar daerah, tidak hanya dari daerah ini, ada yang dijual lagi, untuk ternak, atau dikonsumsi sendiri" (Wawancara pada tanggal 8 Oktober 2020).

Informan di atas menjelaskan bahwa lokasi Pasar Sapi/ Blante ini hanya sekali berpindah tempat ke seberang jalan. Itu pun masih merupakan bagian dari lokasi pasar yang sebenarnya. Meskipun demikian, pasar tersebut selalu ramai dikunjungi dari zaman dahulu. Ada ratusan sapi yang dibawa penjual ke lokasi tersebut dari berbagai daerah, bahkan dari luar provinsi sekalipun. Pembeli ada juga yang mengkonsumsi sendiri, diternakkan, bahkan menjual daging sapinya hingga ke pulau Jawa.

Berdasarkan observasi peneliti di pagi hari, lokasi Pasar Sapi/ Blante ini masih sepi. Hanya terlihat beberapa orang pedagang sapi saja yang datang dengan jumlah sapi yang belum terlalu banyak. Secara fisik, bangunan Pasar Sapi/ Blante memang sudah terlihat agak tua bahkan dinding-dinding pasar sudah terlihat menghitam yang mengindikasikan sebagai bangunan tua peninggalan sisa-sisa bangunan dari masa lalu. Dinding-dinding itu pun juga sudah tidak utuh lagi. Sementara, lapangan yang luas di tengah pasar lebih mirip dengan tempat menggembala sapi di desa pada umumnya karena belum tersentuh oleh modernisasi.

Menurut teori Fungsionalisme Struktural Parsons, struktur masyarakat dan antar hubungan berbagai struktur tersebut dilihat saling mendukung menuju keseimbangan dinamis. Pandangannya pada masyarakat sebagai sebuah sistem yang terdiri dari bagian-bagian atau sub sistem yang saling tergantung. Teori ini menganggap integrasi sosial merupakan fungsi utama dalam sistem sosial. Kunci menuju integrasi sosial menurut Parsons adalah proses keterkaitan antara sistem kepribadian, sistem budaya, dan sistem sosial, atau dengan kata lain, stabilitas sistem.

Pasar Sapi/ Blante sebagai bagian dari sistem sosial, khususnya sistem budaya di mana mengandung nilai sejarah pekerjaan masyarakat Minahasa berupa jual beli sapi yang sudah mereka lakukan secara turun-temurun sampai ke generasi sekarang ini. Pasar ini berfungsi melestarikan nilai-nilai sejarah tersebut sehingga dari generasi ke generasi nilai tersebut tetap tertanam di dalam diri masyarakat Minahasa.

\section{Memupuk Sikap Toleransi}

Masyarakat Indonesia bersifat religius, sehingga berbagai aspek perilaku kehidupan tidak dapat dilepaskan dari nilai-nilai religius. Oleh karena itu salah satu ciri dari local genius biasanya 'sangat terkait dengan sistem kepercayaan. Para pedagang dan pembeli di Pasar Sapi/ Blante tidak hanya berasal dari masyarakat setempat tetapi banyak juga dari mereka yang berasal dari luar kecamatan atau kabupaten hingga dari luar provinsi. Meskipun mayoritas masyarakat Minahasa beragama kristen, namun semenjak dahulu kala masyarakat di sini sudah terbiasa beradaptasi dengan agama lainnya. Hal itu dikarenakan pendatang yang berkunjung ke pasar tersebut tidak hanya terdiri dari beragam suku bangsa tetapi juga berasal dari agama

Jurnal Socius: Journal of Sociology Research and Education Vol. 8, No. 2, Th. 2021 
yang berbeda-beda. Seperti agama Islam, Hindu, dan lain sebagainya, namun tetap diterima dalam pergaulan masyarakat setempat.

Seperti yang dingkapkan oleh YM (58 Tahun) sebagai berikut.

“...Kita nyanda pernah pikir soal apa agama orang yang datang ke sini, ya kalau datang pembeli kita layani sebagai pembeli, begitupun kalau sebagai penjual ata pendatang nyanda ada perbedaan, sama saja bagi kita bahkan kita sambut seperti keluarga sandiri” (Wawancara pada tanggal 8 Oktober 2020).

Artinya:

“...Kita tidak pernah pikirkan soal apa agama orang yang datang ke sini, ya kalau datang pembeli kita layani sebagai pembeli, begitupun kalau sebagai penjual atau pendatang tidak ada perbedaan, sama saja bagi kita bahkan kita sambut seperti keluarga sendiri" (Wawancara pada tanggal 8 Oktober 2020).

Informan di atas menyebutkan bahwa masyarakat setempat memiliki toleransi yang tinggi terhadap perbedaan agama, bahkan memperlakukan sama setiap orang meski orang yang datang ke Pasar Sapi/ Blante dengan agama yang berbeda-beda. Keberadaan Pasar Sapi/ Blante menjadi muara bagi pertemuan berbagai masyarakat yang datang baik hanya sebagai pengunjung, maupun sebagai penjual dan pembeli. Disinilah terlihat bahwa dari segi religi, masyarakat Minahasa mengimplementasikannya dengan menghargai perbedaan keyakinan di antara mereka dan masyarakat lainnya yang datang ke Pasar Sapi/ Blante. Tidak ada diskriminasi dalam melakukan jual beli bagi mereka yang berbeda keyakinan. Bahkan tidak ada juga larangan bagi orang-orang yang berberda agama dalam menggunakan atribut agamanya. Misalnya, tidak adanya larangan berhijab bagi yang muslim, dan lain sebagainya selama masih dalam batas kewajaran dan tentu juga harus menghargai kebudayaan masyarakat setempat. Hal ini terlihat dari beragamnya penjual, pembeli dan pengunjung Pasar Sapi/ Blante ini, ML (60 Tahun) salah satunya.

“...Kita dari Kota Manado kebetulan ada mengunjungi anak ke sini makanya sekalian kita belanja, kita beragama Islam tapi nyanda pernah mengalami dikecewakan oleh pedagang di sini, cuma pandai-pandai kita jo bergaul deng orang sini inshaAllah hubungannya tetap baik. Belanja seperti biasa no, batawar itu wajib dang, lagian kita so tahu dp harga yang biasa kita beli paling beda-beda sadiki jo" (Wawancara pada tanggal 8 Oktober 2020).

Artinya:

“...Saya dari Kota Manado kebetulan ada mengunjungi anak ke sini makanya sekalian kita belanja, kita beragama Islam tapi tidak pernah mengalami dikecewakan oleh pedagang di sini, cuma pandai-pandai kita saja bergaul dengan orang di sini inshaAllah hubungannya tetap baik. Belanja seperti biasa juga, tawarmenawar itu wajib, lagian kita sudah tahu berapa harga yang biasa kita beli paling beda-beda sadiki saja” (Wawancara pada tanggal 8 Oktober 2020).

Informan di atas merupakan salah satu masyarakat Manado yang beragama Islam dan sedang melakukan kunjungan ke Pasar Sapi/ Blante. Selama bertransaksi dengan penjual dan masyarakat sekitar Pasar Sapi/ Blante tidak ditemukan adanya diskriminasi terhadapnya. Hanya saja dalam transaksi jual beli tentunya kemampuan tawar menawar suatu barang ditentukan oleh si pembeli dan penjual itu sendiri. Semakin lihai pembeli menawar barang 
tersebut maka harga yang sesuai dengan keinginan si pembeli tentunya akan tercapai. Sebaliknya, semakin piawai penjual dalam mendagangkan barang dagangannya maka semakin laku barang dangangannya sesuai dengan standar penjualan yang dikehendakinya.

Keterbukaan sifat para pedagang dalam menerima perbedaan menyebabkan para pembeli menyenangi kunjungan ke Pasar Sapi/ Blante tersebut. Begitu juga dengan penjual, mereka merasa senang apabila banyak pengunjung pasar yang datang mengunjungi lapaknya. Asalkan mereka sopan, dan tidak melenceng dari norma-norma masyarakat setempat tentunya para pedagang juga menyambut dengan senang hati.

Berdasarkan observasi peneliti secara langsung terhadap pedagang sapi maupun pembeli di Pasar Sapi/ Blante, umumnya mereka sangat menerima setiap orang yang datang. Setiap pembeli yang berbelanja di pasar tersebut akan diberikan bentuk pelayanan yang sama dengan pelayanan kepada masyarakat asli di sini. Semuanya terasa normal seperti halnya ketika berbelanja di pasar tradisional lainnya. Kemudian juga terlihat bahwa pedagang di Pasar Sapi/ Blante sangat multikultural dan menjunjung tinggi kerukunan antar umat beragama. Hal itu dapat dilihat dari interaksi yang terjadi antara pedagang muslim dan pembeli non-muslim, pedagang non-muslim dengan pembeli muslim, serta pedagang maupun pembeli dari agama lainnya. Perasaan terasing tidak dirasakan mereka karena interaksi berjalan seperti di lingkungan pasar pada umumnya.

Hal itu seperti ulasan yang disampaikan oleh Joko Tri Haryanto dalam tulisannya yang berjudul Local Wisdom Supporting Religius Harmony in Tengger Community, Malang, East Java, Indonesia menjelaskan bahwa model kerukunan beragama dapat ditemui pada kearifan lokal masyarakat dalam berbagai bentuk tradisi dan norma sosial. Tradisi tersebut terbentuk dari pengetahuan lokal mereka bahwa setiap orang membutuhkan bantuan orang lain oleh karena itu mereka pun harus bersedia membantu orang lain (Haryanto, 2014).

Dilihat dari teori struktural fungsional Parson maka Pasar Sapi/ Blante menjadi salah satu faktor yang mempersatukan masyarakat Minahasa, karena didalam proses sosialnya seperti pedagang, pembeli, pengunjung, dan pihak-pihak lainnya yang ada di pasar ini memiliki kepercayaan atau agama yang berbeda-beda. Tidak adanya larangan atau sekat antara yang beragama Kristen, Islam, dan agama lainnya menunjukkan bahwa fungsi pasar ini sudah terpenuhi dengan baik. Di pasar ini tidak akan sulit menemukan pedagang muslim maupun non-muslim baik sebagai penjual, pembeli, maupun pengunjung.

Dengan demikian, dapat dikatakan bahwa pasar ini dapat dijadikan wadah bagi masyarakat sebagai ajang mencari nafkah sekaligus pemeliharaan nilai-nilai religius dalam memelihara kerukunan hidup antar umat beragama. Melalui kegiatan-kegiatan pasar ini, masyarakat dapat menjalin komunikasi dan kerjasama, baik dengan orang yang seagama maupun yang berlainan agama. Tentunya, hubungan keagamaan terpelihara melalui pasar dengan terpeliharanya rasa saling bekerja sama agar kegiatan ekonomi ini berjalan dengan apik dan damai.

\section{Tempat Berinteraksi Antar Masyarakat Minahasa dan Masyarakat Luar}

Di Pasar Sapi/ Blante ada beberapa kategori orang-orang yang melakukan jual beli sapi, yaitu sebagai pemilik, penjual, dan sebagai pembeli. Pertama disebut pemilik, yakni orang yang memiliki sapi atau bisa juga disebut tuan dari sapi-sapi tersebut. Tidak semua pemilik sapi langsung menjualnya kepada pembeli namun ada juga sebagian pemilik menjualkan sapinya melalui penjual tentunya dengan pembagian keuntungan. Biasanya para pemilik sudah menetapkan harga pokok kepada penjual sehingga jika ingin memperoleh keuntungan dari penjualan sapi itu maka penjual harus bisa bermain harga. Namun, ada juga pemilik yang langsung turun tangan menjual sapinya kepada pembeli.

Jurnal Socius: Journal of Sociology Research and Education Vol. 8, No. 2, Th. 2021 
Kedua disebut penjual. Penjual adalah orang yang dipercaya pemilik untuk menjualkan sapi-sapinya dimana pemilik sudah memberikan harga kepada penjual untuk kemudian ditawarkan kepada pembeli. Dalam hal ini antara pemilik dan penjual sama-sama mendapatkan keuntungan dari proses jual beli tersebut. Ketiga disebut pembeli. Pembeli adalah setiap orang yang membeli sapi, baik untuk dijadikan hewan ternak, dijual kembali dagingnya, ataupun dijual kembali sapinya kepada orang lain. Pembeli di pasar ini tidak pernah dibeda-bedakan secara SARA (Suku Agama Ras dan Antargolongan), semua orang diterima dengan tangan terbuka untuk membeli sapi di pasar ini.

Hal ini seperti yang diungkapkan oleh IL (61 Tahun) sebagai berikut.

“...Ada beberapa kategori orang-orang yang ada di pasar sapi ini, ada pemilik, penjual, dan pembeli. Pemilik adalah yang punya sapi, penjual ya seperti kamikami ini menjualkan sapi-sapi pemilik, sebenarnya ada juga pemilik yang langsung sebagai penjual, kemudian pembeli yang membeli sapi untuk dijual lagi, dipelihara, maupun dikonsumsi sandiri" (Wawancara pada tanggal 8 Oktober 2020).

Artinya:

“...Ada beberapa kategori orang-orang yang ada di pasar sapi ini, ada pemilik, penjual, dan pembeli. Pemilik adalah yang punya sapi, penjual ya seperti kami-kami ini menjualkan sapi-sapi pemilik, sebenarnya ada juga pemilik yang langsung sebagai penjual, kemudian pembeli yang membeli sapi untuk dijual lagi, dipelihara, maupun dikonsumsi sendiri" (Wawancara pada tanggal 8 Oktober 2020).

Kemudian juga ditambahkan PT (46 Tahun) sebagai berikut,

“...Setiap orang yang datang ke pasar ini baik sebagai penjual maupun pembeli biasanya akan mudah dikenali kecuali yang baru-baru berkunjung. Sehingga dengan saling mengenal tersebut maka akan mudah mendeteksi jika ada sapi curian yang dijual di sini. Kalau ketahuan maka sapinya akan ditahan bersama orangnya dan akan dilaporkan kepada pihak yang berwajib" (Wawancara pada tanggal 8 Oktober 2020).

Artinya:

“...Setiap orang yang datang ke pasar ini baik sebagai penjual maupun pembeli biasanya akan mudah dikenali kecuali yang baru-baru berkunjung. Sehingga dengan saling mengenal tersebut maka akan mudah mendeteksi jika ada sapi curian yang dijual di sini. Kalau ketahuan maka sapinya akan ditahan bersama orangnya dan akan dilaporkan kepada pihak yang berwajib" (Wawancara pada tanggal 8 Oktober 2020).

Dengan demikian, Pasar Sapi/ Blante menjadi organisasi sosial yang terbentuk atas dasar persatuan dan kepercayaan antara satu dengan yang lainnya untuk mencapai tujuan mereka secara bersama-sama. Oleh karena itu, masyarakat setempat menjadikan pasar itu sebagai salah satu strategi dalam mempertahankan nilai-nilai dan norma yang memang telah terbentuk sejak dahulu kala serta sebagai wadah berinteraksi sekaligus untuk memelihara harmoni antar setiap individu yang ada. Hal ini seperti dalam tulisan Joko Tri Hary Anto yang berjudul The Dynamics of Intra-Religius Harmony Within Moslems in Relation Ethnic Religius Issue in Central Kalimantan, yang menjelaskan bagaimana strategi adaptasi yang dilakukan untuk memelihara harmoni secara kultural melalui revitalisasi dan akulturasi budaya dan nilai-nilai lokal, serta secara struktural dengan politik uniformitas baik yang dilakukan oleh pranata adat maupun pemerintah (Haryanto, 2013). 
Berdasarkan observasi peneliti di Pasar Sapi/ Blante, informasi dengan mudah diperoleh tentang jual beli sapi. Disini, pembeli akan langsung dihampiri oleh para penjual sapi sehingga kesempatan untuk bertanya tentang harga sapi yang diperjualbelikan lebih jelas bahkan diarahkan oleh penjual untuk melihat sapi-sapi yang tersedia. Mereka juga menjelaskan kondisi sapi dan harganya, jika pembeli berkeinginan membeli sapi maka kegiatan tawar-menawar harga sudah bisa dilakukan. Para pedagang sapi di sini menjelaskan bahwa mereka sebisa mungkin menjaga kepercayaan pembeli dengan mengkoordinir supaya tidak ada sapi curian yang dijual di pasar tersebut karena di antara mereka juga sudah saling mengenal, kalaupun ada orang baru itu akan mudah untuk mendatanya.

Pasar Sapi/ Blante merupakan wadah untuk mengintegrasikan tidak hanya antar anggota masyarakat Minahasa, akan tetapi juga masyarakat yang berada di luar suku bangsa Minahasa. Proses sosial masyarakat yang berinteraksi dengan berbagai latar belakang dari pedagang, pengunjung, dan pembeli di pasar tersebut diterima kehadirannya sebagai saudara tanpa adanya diskriminasi sehingga integrasi dan keseimbangan yang dijelaskan oleh Parson dalam teorinya struktural fungsional sudah diimplementasikan di Pasar Sapi/ Blante Kawangkowan ini.

\section{"Sitou Timou Tumou Tou" bagi masayarakat Minahasa}

Si Tou Timou Tumou Tou (Masinambow, Paat, \& Sondakh, 1991) ialah suatu ungkapan filosofis yang dalam dan menjadi sebuah "quote" terkenal dari seorang tokoh Minahasa yang sekaligus menjadi pahlawan nasional yaitu DR. G.S.S.J (Sam) Ratu Langie. Pada saat buku tersebut ditulis sempat disinggung tentang keadaan diri orang Minahasa. Dikatakan bahwa terjadi pelunturan jati diri orang Minahasa yang ditandai dengan jarangnya mereka menggunakan bahasa daerah sub suku di pedesaan. Selain itu, kepribadian yang umum dimiliki orang Minahasa seperti sifat kebersamaan, tolong-menolong, taat dan disiplin yang biasa disebut Mapalus atau Maendo dilihat semakin luntur praktiknya dalam keseharian. Nilai-nilai luhur yang terkandung dalam ungkapan persatuan, kasiang, saling membantu dan lain-lain hanya tertinggal sebagian kecil saja dan lainnya hanya slogan semata. Lebih banyak melekat sifat konsumeristik, hedonis, dan feodalis pada diri orang Minahasa. Oleh sebab itu, masalah tersebut harus dipecahkan dengan keturutsertaan dan pembangunan diri orang Minahasa sebagai bagian manusia Indonesia ke arah pengembangan nilai-nilai jati diri yang positif dan kondusif bagi peningkatan peran sertanya. Dalam prinsip hidup Si Tou Timou Tumou Tou ini mengandung anasir luhur tentang jati diri, sosok manusia Minahasa/Kawanua yang ideal apabila dapat memanusiakan manusia yang lain.

Seperti yang diungkapkan oleh YN (53 Tahun) sebagai berikut.

“...Semua orang diterima di sini, asalkan berniat baik dan menghargai nilai-nilai yang kami anut di sini, orang sini juga nyanda ganggu-ganggu, baik penjual, pemilik, pengunjung yang datang diterima baik di sini" (Wawancara pada tanggal 08 Oktober 2020).

Artinya:

“...Semua orang diterima di sini, asalkan berniat baik dan menghargai nilai-nilai yang kami anut di sini, orang di sini juga tidak pernah mengganggu, baik penjual, pemilik, pengunjung yang datang diterima baik di sini" (Wawancara pada tanggal 8 Oktober 2020).

Seperti halnya peneliti yang baru pertama kali datang ke lokasi dan langsung meminta izin untuk melakukan wawancara disambut dengan baik bahkan sangat antusias tidak hanya oleh satu atau dua orang tapi, setiap orang yang peneliti temui di pasar ini. Mereka mengatakan 
bahwa "torang samua basudara" yang artinya kita semua bersaudara. Hal tersebut merupakan penjabaran dan implementasi lebih lanjut dari filosofi masyarakat Minahasa itu sendiri.

Keseharian pedagang di Pasar Sapi/ Blante ini sangat erat dalam penerapan filosofi hidup masyarakat Minahasa yang dikenal dengan "Si Tou Timou Tumou Tou". Hal ini tergambar dari cara mereka menyambut tamu yakni orang-orang luar yang datang ke pasar ini baik sebagai pedagang, pengunjung maupun sebagai pembeli. Setiap orang dari manapun asalnya, sukunya, agamanya dan latar belakang lainnya akan diterima sebagai keluarga. Maka tidak heran jika di pasar ini kita akan menemukan beragam latar belakang penjual sapi, pengunjung dan juga pembeli yang datang dari berbagai daerah yang ada di Sulawesi Utara maupun yang ada di luar Sulawesi Utara.

\section{Ladang Mata Pencaharian Masyarakat}

Mata pencaharian masyarakat setempat yang sudah dilakukan secara turun temurun adalah bekerja menjual sapi baik sebagai pemilik sapi maupun hanya sebagai penjual saja. Selain itu, mata pencaharian lainnya yang digeluti oleh masyarakat Minahasa seperti bertani, pengrajin, pedagang, dan lain sebagainya. Kehidupan ekonomi mereka dengan menjual sapi tergolong cukup stabil karena komoditas sapi yang diperjualbelikan di sini tidak pernah ada habisnya. Bahkan di masa pandemi seperti sekarang ini jumah sapi yang diperjualbelikan tidak mengalami penurunan yang berarti, termasuk juga soal kuantitas sapi yang terjual juga tidak mengalami penurunan. Harga sapinya pun rata-rata masih sama tidak mengalami kenaikan atau penurunan. Harga lebih banyak ditentukan oleh kesepakatan transaksi antara penjual dan pembeli asal senang sama senang, begitu mereka menyebutnya.

Seperti yang diungkapkan oleh HN (47 Tahun) sebagai berikut.

“..Di masa korona bagini nyanda terlalu berpengaruh terhadap penjualan sapi, kebutuhan terhadap sapi masih stabil, jumlah sapi yang terjual pun masih seperti hari biasa sebelum korona datang, pembeli pun nyanda berkurang" (Wawancara pada tanggal 8 Oktober 2020).

Artinya:

“...Di masa korona seperti ini tidak terlalu berpengaruh terhadap penjualan sapi, kebutuhan terhadap sapi masih stabil, jumlah sapi yang terjual pun masih seperti hari biasa sebelum korona datang, pembeli pun tidak berkurang" (Wawancara pada tanggal 8 Oktober 2020).

Berdasarkan hasil observasi peneliti di Pasar Sapi/ Blante Kawangkowan tersebut, keramaian pedagang terjadi di siang hari meskipun di pagi hari juga sudah mulai terlihat beberapa mobil berdatangan membawa sapi. Satu mobil ada yang membawa dua ekor sapi atau tiga ekor sapi tergantung ukuran mobilnya. Sementara itu, para penjual sudah cukup ramai di lokasi menunggu para pemilik sapi membawa sapinya ke lokasi tersebut.

Dengan demikian, realitas di Pasar Sapi/ Blante ini dengan mudah menemukan orangorang dengan latar belakang yang beragam atau multikultural. Setiap elemen masyarakat di pasar ini saling menerima dan memahami satu sama lain tanpa memandang latar belakang budayanya. Berarti setiap elemen yang terlibat dalam proses sosial tersebut sudah menjalankan fungsinya sehingga terciptanya suatu masyarakat yang teratur atau menjaga nilai-nilai keseimbangan seperti yang diungkapkan oleh Parson dalam teori struktural fungsionalnya.

\section{Sebagai Wadah Pelestarian Bahasa Daerah Minahasa}


Seiring berkembangnya zaman, bahasa anak-anak, remaja dan orang dewasa di Minahasa juga sudah banyak dipengaruhi berbagai aspek, seperti media sosial, internet dan kontenkonten yang berkaitan dengan bahasa di luar Minahasa. Sudah banyak diantara mereka yang mencampurbaurkan bahasa Minahasa dengan bahasa luar Minahasa.

Seperti yang diungkapkan oleh tante SL (38 Tahun) sebagai berikut.

“...Memang anak muda sekarang sudah banyak berubah dari kami waktu muda dulu, kita sering dengar anak muda Minahasa kong pakai bahasa Indonesia waktu bakudapa di warung-warung atau berselisih jalan di pasar ini" (Wawancara pada tanggal 8 Oktober 2020).

“...Memang anak muda sekarang sudah banyak berubah dari kami waktu muda dulu, saya sering dengar anak muda Minahasa tapi pakai bahasa Indonesia waktu bertemu di warung-warung atau berselisih jalan di pasar ini" (Wawancara pada tanggal 8 Oktober 2020).

Informan di atas menjelaskan bahwa perubahan bahasa tidak dapat dielakkan seiring dengan perubahan zaman. Namun, perlu disadari bahwa bahasa adalah wujud nyata dari sebuah kebudayaan suku bangsa, yang tetap harus dilestarikan. Hal itu dikarenakan perkembangan zaman menyebabkan nilai-nilai budaya akan membaur dengan bahasa lainnya akibat dari pengaruh globalisasi. Sebagaimana diketahui berbahasa itu sendiri tidak terlepas dari sebuah komunikasi. Komunikasi adalah proses penyampaian pesan kepada komunikan, ketika pesan yang disampaikan tidak sesuai dengan harapan si penerima maka kemungkinan besar akan terjadi miskomunikasi yang berujung pada kesalah pahaman (Fathimah \& Eriyanti, 2018).

Tata karma dalam berkomunikasi menjadi sesuatu yang harus tetap terpelihara. Nilainilai inilah yang masih melekat dalam masyarakat di Pasar Sapi/ Blante tersebut. Hal itu terlihat dari sedikitnya catatan tentang perselisihan yang pernah terjadi di pasar ini. Disamping itu pasar ini juga menjadi wadah bagi masyarakat untuk tetap mempelihara kelestarian bahasabahasa lokal. Caranya adalah tetap berkomunikasi dengan menggunakan bahasa daerah, tapi tidak tertutup kemungkinan pula mereka untuk menggunakan bahasa Indonesia dalam ketika berkomunikasi dengan lawan bicara dari daerah luar.

Seperti yang diungkapkan oleh IL (61 Tahun) sebagai berikut.

“...Umumnya anak muda memang sudah banyak perubahan, meski kita dengar waktu bermain bersama mereka masih kental menggunakan bahasa Minahasa, namun kalau bakudapa deng orang luar mereka so campur itu bahasa deng bahasa Indonesia" (Wawancara pada tanggal 8 Oktober 2020).

“...Umumnya anak muda memang sudah banyak perubahan, meski saya dengar waktu bermain bersama mereka masih kental menggunakan bahasa Minahasa, namun kalau bertemu dengan orang luar mereka sudah campur itu bahasa dengan bahasa indonesia" (Wawancara pada tanggal 8 Oktober 2020).

Wawancara di atas menjelaskan bahwa di Pasar Sapi/ Blante masih ditemukan dan didengar secara langsung komunikasi antara masyarakat menggunakan bahasa daerah Minahasa. Bahkan ketika mereka berkomunikasi dengan orang yang berasal dari luar Minahasa, bahasa Minahasa masih digunakan meskipun dicampur dengan bahasa Indonesia. Berdasarkan realitas tersebut berarti Pasar Sapi/ Blante ini masih memiliki fungsi penting dalam menjaga nilai-nilai kearifan lokal masyarakat Minahasa.

Bahasa sebagai salah satu unsur budaya sangat penting peranannya dalam mempersatukan suatu masyarakat. Di Pasar Sapi/ Blante pada umumnya setiap orang akan 
menggunakan bahasa Minahasa meskipun itu pendatang ataupun pengunjung. Meskipun tidak berbahasa Minahasa sepenuhnya, para pendatang ini sudah menggabungkan bahasa masyarakat setempat dengan bahasa asli mereka. Ada yang berbahasa Jawa dicampur dengan bahasa Minahasa, bahasa Minang dicampur dengan bahasa Minahasa, dan lain sebagainya. Hal ini tentu penting untuk berkomunikasi dan saling memahami antar setiap orang yang berinteraksi di Pasar Sapi/ Blante ini. Ini berarti pasar ini sudah menjalankan fungsinya sebagai tempat melestarikan bahasa daerah setempat yaitu bahasa Minahasa sekaligus menjadi faktor yang mempersatukan (mengintegrasikan) setiap orang yang berinteraksi di Pasar Sapi/ Blante Kawangkowan ini. Hal ini merupakan penjabaran lebih lanjut dari teori struktural fungsional Parson di mana pasar sebagai sistem budaya menjadi bagian penting dalam memelihara bahasa daerah Minahasa dan mempersatukan masyarakatnya.

\section{Simpulan}

Hasil penelitian ini menunjukkan bahwa keberadaan Pasar Sapi/ Blante fungsional bagi masyarakat Minahasa. Dilatarbelakangi oleh aktivitas jual beli sapi yang sudah dilakukan secara turun temurun di Pasar Sapi/ Blante tersebut menyebabkan aktivitas ini menjadi mata pencaharian utama masyarakat. Mereka yang mengunjungi pasar tersebut bukan hanya pedagang dan pembeli dari sekitaran Minahasa akan tetapi juga masyarakat yang juga berasal dari luar Minahasa dengan beragama sukubangsa dan agama. Kedatangan mereka dilayani dengan baik oleh masyaarakat di Pasar Sapi/ Blante tanpa membedakan sukubangsa dan agama mereka tersebut. Pedagang di sini sangat multikultur dan menjunjung tinggi kerukunan antar umat beragama. Hal itu terlihat jelas dari interaksi yang terjadi antar pedagang muslim dengan pedagang non-muslim maupun sebaliknya. Perasaan terasing tidak dirasakan mereka karena interaksi berjalan seperti di lingkungan pasar pada umumnya. Jadi, kehadiran pasar ini dapat berfungsi positif dalam mendukung integrasi sosial masyarakat Minanahasa.

Meskipun jika dicermati, Pasar Sapi/ Blante juga menjadi jawaban atas tuntutan modernisasi pasar. Nilai-nilai yang terkandung dalam "Sitou Timou Tumou Tou' berupa nilai tolong menolong, kebersamaan, taat dan disiplin yang biasa disebut mapalus atau maendo semakin luntur. Nilai-nilai luhur yang terkandung dalam ungkapan persatuan, kasiang, saling membantu hanya Sebagian kecil saja dipakai masyarakat. Istilah itu lebih banyak digunakan sebagai slogan saja. Keberadaan Pasar Sapi/ Blante menjadi alternatif dipeliharanya nilai-nilai filosifi masyarakat Manahasa tersebut supaya tetap lestari dalam masyarakat.

\section{Rujukan}

Afrizal, A. (2014). Pendekatan Penelitian Kualitatif: Sebuah Upaya Mendukung Penggunaan. Jakarta: Rajawali Press.

Bagit, V. F. (2017). Orientasi Nilai Budaya Di Kalangan Perempuan Terhadap Model Pakaian Di Kota Manado. Holistik, 10(19).

Basyari, H., \& Warii, I. (2014). Nilai-Nilai Kearifan Lokal (Local Wisdom) Tradisi Memitu pada Masyarakat Cirebon (Studi Masyarakat Desa Setupatok Kecamatan Mundu). Edunomic: Jurnal Ilmiah Pendidikan Ekonomi, 2(1), 47-56.

Denzin, N. K., \& Lincoln, Y. S. (2009). Handbook of Qualitaive Research. Yogayakarta: Pustaka Pelajar.

Fathimah, S., \& Eriyanti, F. (2018). Mapping Factors That Support Social Integration of Minangkabau Community in Luhak Agam. ICESST.

Fatmawati, N., \& Prasetya, A. I. (2021). Tourism Destination Based on Local Values in Wonosoco Village, Kudus Regency, Indonesia. Local Wisdom: Jurnal Ilmiah Kajian Kearifan Lokal, 13(1), 13-22. https://doi.org/https://doi.org/10.26905/lw.v13i1.4723

Jurnal Socius: Journal of Sociology Research and Education Vol. 8, No. 2, Th. 2021 
Haryanto, J. T. (2013). Dinamika Kerukunan Intern Umat Islam dalam Relasi Etnisitas dan Agama di Kalteng. Analisa, 20(1), 13. https://doi.org/10.18784/analisa.v20i1.2

Haryanto, J. T. (2014). Kearifan Lokal Pendukung Kerukunan Beragama Pada Komuntias Tengger Malang Jatim. Analisa, 21(2), 201. https://doi.org/10.18784/analisa.v21i02.15

Lamadirisi, M., Fathimah, S., \& Sidik, S. (2020). Mapping Factors Supporting Social Integration of the Minangkabau Community in Luhak Tanah Datar. ICSS.

Masinambow, E. K. M., Paat, G., \& Sondakh, A. J. (1991). Si Tou Timou Tumou Tou : Peranan Manusia Minahasa Dalam Pembangunan Nasional. Jakarta: Kerukunan Keluarga Kawanua.

Miles, M. B., \& Huberman, A. M. (1994). Qualitative Data Analysis. England: Sage Publications.

Salem, S., Veronika, T. ., \& Mesra, R. (2020). Preservation of Local Language Culture in Toundanouw Village District Southeast Minahasa Regency. ICSS.

Setyabudi, I., Santoso, D. K., \& Albina, K. (2021). "Gawai": Cultural Activities in the Shroud of Jangkang Bokidoh Dayak Tribe Traditional Architecture in Balai Sebut Village. Local Wisdom: Jurnal Ilmiah Kajian Kearifan Lokal, 13(1), 36-50. https://doi.org/https://doi.org/10.26905/lw.v13i1.4816

Suwarlan, S. A. (2021). Spatial Adaptation of Traditional Javanese Houses in Landscape Design of Senaputra Cultural Tourism Park. Local Wisdom: Jurnal Ilmiah Kajian Kearifan Lokal, 13(1), 1-12. https://doi.org/https://doi.org/10.26905/lw.v13i1.4770

Syafrini, D., Nurdin, M., Sugandi, Y. S., \& Miko, A. (2020). The impact of multiethnic cultural tourism in an Indonesian former mining city. Tourism Recreation Research, 45(4), 511525 . 